\title{
The White Stone Band of the Kimmeridge Clay Formation, an integrated high- resolution approach to understanding environmental change
}

\author{
S. J. PEARSON ${ }^{1,2}$, J. E. A. MARSHALL ${ }^{1}$ \& A. E. S. KEMP ${ }^{1}$ \\ ${ }^{1}$ School of Ocean and Earth Science, University of Southampton, Southampton Oceanography Centre, European Way, \\ Southampton SO14 3ZH, UK (e-mail: jeam@soc.soton.ac.uk) \\ ${ }^{2}$ Present address: 1514A Dominion Road Extension, Mt Roskill, Auckland, New Zealand
}

\begin{abstract}
The Kimmeridge Clay is a Jurassic mudrock succession that shows Milankovitch Band climatic cyclicity. A key issue is to determine how the subtle changes that define this cyclicity result from climatic change. Using material from the Natural Environment Research Council Rapid Global Geological Events (RGGE) Kimmeridge Drilling Project boreholes, the White Stone Band was investigated at the lamination scale using backscattered electron imagery and quantitative palynofacies. Fabric analysis shows the lamination to represent successive deposition of coccolith-rich and organic-matter-rich layers. Individual laminae contain unsorted palynological debris with a consistent ratio of marine and terrestrial components. Such mixed organic matter input is interpreted as the result of storm transport. Linking water column processes to laminae deposition suggests seasonal input with a coccolith bloom followed by a more diverse assemblage including dinoflagellates and photosynthetic chlorobiacean bacteria. As the photic zone extended into the euxinic water column organic matter export to the sea bed underwent minimal cycling through oxidation and subsequently became preserved through sulphurization with greatly increased sequestration of carbon. This was significantly increased by late season storm-driven mixing of euxinic water into the photic zone. Increased frequency of storm systems would therefore dilute the coccolith input to give an oil shale. Hence climatically induced changes in storm frequency would progressively vary the organic content of the sediment and generate the climate cycle signal.
\end{abstract}

Keywords: Milankovitch theory, Kimmeridge Clay, organic matter, high-resolution methods, climate change.

It is now generally accepted that the sedimentary cyclicity observed in many geological successions owes its origin to orbital forcing within the Milankovitch Band. The argument for a climatic origin for this cyclicity generally lies in the time-series analysis of long stratigraphic sequences (e.g. Weedon 2003). What is less clear is how the cyclic climatic change translated into the visible or measurable differences that we use to recognize these time-series within the rock succession.

In the British Jurassic succession there are a number of classic cyclic sequences (e.g. House \& Gale 1995; Weedon et al. 1999). Notable amongst these is the Kimmeridge Clay Formation as seen in the type succession in Dorset, UK. Here the Kimmeridge Clay Formation is of Late Jurassic age and although there has been considerable discussion as to its depositional environment (e.g. Oschmann 1988, 1990; Miller 1990; Tyson 1996; Sælen et al. 2000) it is generally agreed that it was deposited in a marine shelf environment with both a restricted circulation and variable oxygen content.

The Kimmeridge Clay Formation is very distinctive in that there is a significant contribution of biogenic input (primarily coccoliths and organic matter) to the sediment, i.e. a 'blackchalk'. Generally the cyclicity within the Kimmeridge Clay Formation is subtle and defined by measuring parameters such as the magnetic susceptibility or the organic matter content of the sediments (Weedon et al. 1999). Therefore central to any arguments about the Kimmeridge Clay environment is the role of productivity and/or preservation in the deposition of this organic matter. Recently, substantial progress has been made particularly through the application of biomarkers and compound-specific analyses of $\delta^{13} \mathrm{C}$ (van Kaam-Peters et al. 1997, 1998; Sinninghe Damsté et al. 1998; Sælen et al. 2000; van Dongen et al. 2003).
These show (van Kaam-Peters et al. 1997, 1998; van Dongen et al. 2003) that increased total organic carbon (TOC) values result from increased preservation rather than productivity. The mechanism was the relative upward movement of the lower euxinic water mass into the photic zone. This greatly reduced the possibility of organic matter being oxidized during its descent through the water column. Therefore, significant quantities of carbohydrates reached the sea bed and were subsequently preserved by sulphurization and result in a significantly increased carbon sequestration to the sea-floor sediment.

In addition to the subtle variations in organic matter content that define the Milankovitch-scale cycles, there are also intervals (Morgans-Bell et al. 2001) where the Kimmeridge Clay Formation goes through a more rapid series of alternations (on a millimetre to metre scale) between the end-member lithologies of coccolith limestone and oil shale. If we can understand the mechanisms that caused the Kimmeridge environment to switch between these end-members then we have the potential to understand the controls of cyclic alternation within the longer formation-scale time-series. This study attempts to understand these controls through an integrated high-resolution study of backscattered electron imagery (BSEI) and palynofacies in one of these intervals that is known as the White Stone Band from the white colour imparted by its high coccolith content.

\section{Material and methods}

As part of the Rapid Global Geological Events (RGGE) project three boreholes were drilled through the entire Kimmeridge Clay Formation in its type succession in Dorset, UK (Gallois 2000; Morgans-Bell et al. 2001). From within the Kimmeridge Clay Formation a number of discrete intervals (the White Stone Band, the Freshwater Steps Stone Band, an 
organic-rich interval in the eudoxus Zone and Bed 44; Weedon et al. 2004, fig. 2) were investigated in some detail. We report here on the results of the study of one of these levels, the White Stone Band. Full details of preparation methods have been given by Pearson (2000). The material used was from a pair of boreholes drilled $18 \mathrm{~m}$ apart in Swanworth Quarry, Dorset (SY 96757823). Polished resin-embedded thin sections were prepared from these cores and then used to compile a $\times 20$ photomosaic of the sediment fabrics from the entire White Stone Band. This was used to select the intervals in the White Stone Band cycle where the sediment was laminated and hence where a high-resolution signal could be recognized. Outside these areas, the sediment was homogenized with the loss of the high-resolution signal and the sampling changed to a $1 \mathrm{~cm}^{3}$ block taken every other centimetre. The highresolution samples were acquired by serially slicing blocks of core along lamination using a Testbourne model 850 wire saw. The resulting thin wafers $(0.1-1 \mathrm{~g})$ were then individually analysed for TOC and calcite content (details as given by Morgans-Bell et al. 2001) and a Lycopodium spiked palynological slide (processed following the method of Waterhouse 1995). Some 17 palynofacies categories were determined from over 200 wafers cut from the laminated intervals plus a further 60 lower-resolution samples. In addition, bisaccate pollen size was measured as maximum length and width with the result presented as the squareroot of the product of length $\times$ width. Bisaccate pollen are ubiquitous within Mesozoic and younger strata, have clear modern analogues (e.g. Mudie 1982) and are well known to show the effects of differential transport.

\section{White Stone Band lithology and BSEI fabrics}

The interval studied (Fig. 1) is a $1.2 \mathrm{~m}$ thick composite of coccolith limestone, oil shale and mudstone that lies within the generally homogeneous mudstone interval of the Pectinatites pectinatus Zone of the Upper Kimmeridge Clay. The eponymous band is an $80 \mathrm{~cm}$ thick distinctive white laminated bed of coccolith limestone that has a calcite content of over $80 \%$. Analysis of the calcite content shows that the upper and lower boundaries to this coccolith limestone are transitional with some $20 \mathrm{~cm}$ of calcareous mudstone (about $60 \%$ calcite). Within the White Stone Band interval mudstones the TOC increases (Fig. 1) from the Kimmeridge Clay Formation background value of 2$3 \%$ to about $5 \%$. There are also a number of distinct oil shales. Two of these are the thin $(3 \mathrm{~cm})$ but prominent TOC maxima (35\% in the upper oil shale and $50 \%$ in the middle oil shale) that occur at the calcareous mudstone to coccolith limestone transitions. These peaks are not the result of single analyses but represent some 15 or so analyses from the individual laminae that make up the oil shales. The TOC progressively rises and falls through each oil shale. Beneath the main White Stone Band there is an interval of mudstone and bituminous mudstone with a further thicker $(10 \mathrm{~cm}$, lower oil shale) oil shale. The TOC and calcite analyses show that this is, in fact, a composite of discrete oil shale and coccolith limestones with some four $30-40 \%$ TOC oil shales c. $2 \mathrm{~cm}$ thick. A similar but much less distinct unit separates the middle and upper coccolith limestones. This is a composite interval of three minor TOC peaks with coincident calcite minima.

BSEI of the typical Kimmeridge Clay Formation mudstone fabric shows that the predominant matrix components are clays and coccoliths. Dispersed within this matrix are silt-sized quartz grains, feldspar, pyrite and organic matter. The organic matter varies in morphology from being dispersed within the mineral matrix to discrete organic ribbons. Hence within these mudstones the algal input, both as coccoliths and organic matter, is both diluted by clastic input and mixed with it, laminations being absent.

The calcareous mudstones differ from the mudstone in showing an increase in coccolith content. The coccoliths occur both within the matrix and as distinct lenses several hundred micrometres in length by about $100 \mu \mathrm{m}$ in thickness. Organic content increases in the calcareous mudstones as the wavy organic ribbons become more common. As coccolith content increases the calcareous mudstone passes transitionally to a coccolith limestone (Fig. 2a). Visually these appear well laminated but BSEI examination at a higher magnification (Fig. $2 b$ and c) shows them to be dominated by coccoliths, with the organic matter lamination couplet being thin discontinuous stringers rather than discrete laminae. However, these organic stringers are concentrated within distinct zones separated by purer coccolith limestone. The majority of the matrix is essentially a mass of coccoliths but coccospheres are present frequently in pellet-like aggregations (Fig. 2g).

The oil shales have a TOC content of over $20 \%$ with a calcite content of less than $20 \%$. The bituminous mudstones are thicker units with a TOC content of up to $20 \%$ but with some $40 \%$ calcite. Generally the organic matter is present as diffuse amorphous organic matter (AOM) within the matrix. Alternatively, the organic matter can occur (Fig. 2d and e) as structured lenses and stringers of variable length, thickness and abundance. These are undulose but bedding parallel and frequently drape other components such as quartz silt (Fig. 2e) and carbonate (coccolith) pellets. The TOC peaks that define the oil shales are coincident with peaks in the atomic $\mathrm{H} / \mathrm{C}$ ratio and show that there was an enhanced preservation of organic matter at these levels. However, even within the organic-matter-rich lithologies carbonate is still an important component (Fig. 2e). It occurs as loose coccoliths dispersed within the matrix or as coccolith stringers and pellets. The pellets can contain loose coccolith plates or abundant coccospheres. Coccolith preservation varies

Fig. 1. Distribution of main palynofacies groups within the White Stone Band. The core photograph shows the White Stone Band referenced against the common depth scale (e.g. $197 \mathrm{~m}$ ) and the bed group and bed numbers of Morgans-Bell et al. (2001). The subunits of the White Stone Band are indicated by the following lithological codes: CMST, cementstone; MDST, mudstone; Calc, calcareous, CL, coccolith limestone; OS, oil shale; bit, bituminous; 1 , lower; m, middle; $u$, upper. The intervals of sampling at lamination-level resolution should be noted. The individual sample points are shown on the TOC $\%$ data and demonstrate that the middle and upper oil shales have mid-bed TOC maxima. The lower oil shale is a composite of discrete oil shales that have similar mid-bed TOC maxima. The calcite \% reveals the coccolith limestones and the generally high carbonate content, showing the significant contribution of coccoliths to the sediment. The atomic H/C ratio shows peaks coincident with TOC maxima (very clear in the lower oil shale), indicating increased preservation at these levels. The next six tracks show the abundance of TMP (total marine palynomorphs), TTP (total terrestrial palynomorphs) and STD (structured terrestrial debris, essentially phytoclasts) as particles per gram. In the first three tracks the data are given as absolute abundance (aa) per $\mathrm{g}$ of sediment. The next three tracks are as recalculated absolute abundance per gram of sediment carbonate free (cf). All three categories show coincident peaks, i.e. high terrestrial influx is matched by high marine influx. This is interpreted as showing a lack of differential transport within the system, with the different categories being input as well-mixed pulses during storms. The increased input of all three categories both above and below the upper oil shale should be noted. The final track shows the variation in mean size (as the square root of the length $\times$ width product) of the bisaccate pollen. This is seen as a more direct measure of the degree of transport. The influx of larger-sized bisaccate pollen associated with the oil shales should be noted. 

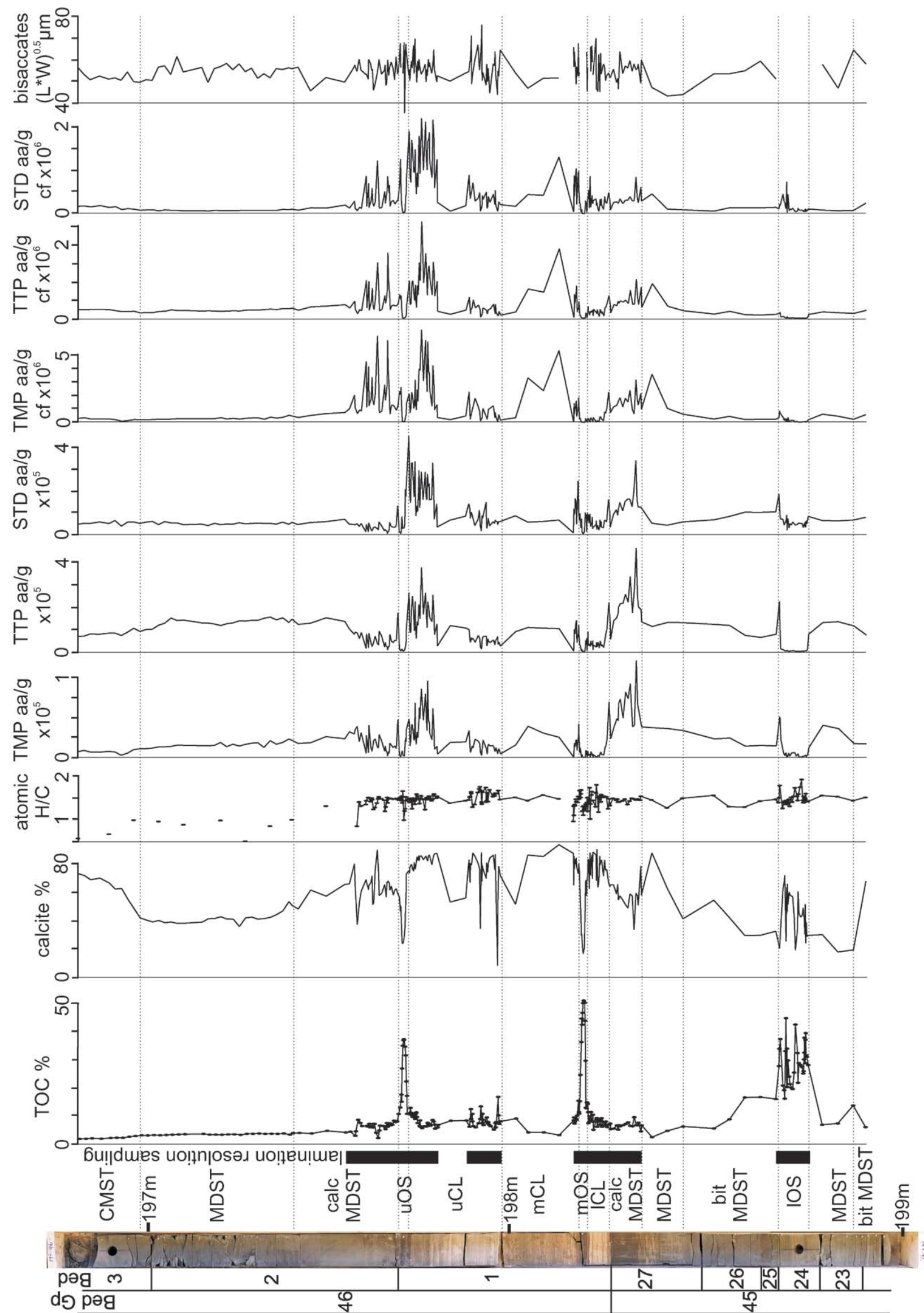
from exceptional within the pellets (Fig. $2 \mathrm{~g}$ ) to barely identifiable within layers of coccolith hash. The final preservational form is the lenses and stringers of sparry euhedral carbonate crystals (Fig. 2f) that represent completely recrystallized coccoliths.

\section{High-resolution palynofacies}

Selected palynofacies elements are shown in Figure 1, where the data are presented both as total abundance and carbonate-free abundance. Other categories, ratios and abundances have been given by Pearson (2000) or are available online at http:// www.geolsoc.org.uk/SUP018207. Within these data a clear separation should be made between the laminated intervals with high-resolution data and the zones without lamination where the data was collected as $1 \mathrm{~cm}^{3}$ composites at $2 \mathrm{~cm}$ intervals. The intervals of high-resolution data are shown in Figure 1. A strong feature of these high-resolution data is that successive samples show highs and lows that give a distinctive sawtooth profile. This is a consequence of the sequential sampling of carbonate-rich and carbonate-poor laminations. In general, the carbonate-poor laminations contain higher abundances of structured palynomorphs than the immediately adjacent carbonate-rich couplet. This sawtooth character is present in both total abundance and carbonate-free datasets.

The most common elements within all the White Stone Band samples are material of terrestrial origin, i.e. spores, pollen (TTP, total terrestrial palynomorphs) and phytoclasts (TSD, total structured debris) from land plants. However, all the groups, both terrestrial and marine (TMP, total marine palynomorphs), have effectively identical profiles and show a strong correlation between their abundances (Fig. 3), i.e. a high abundance of marine palynomorphs (mostly dinocysts) is matched by a high abundance of pollen, spores and phytoclasts. This contrasts with the situation normally seen in marine shelf sediments, where high relative abundances of, for example, pollen and spores are matched by low abundances of marine phytoplankton and vice versa (e.g. Tyson 1995).

Particularly instructive is the effectively continuous highresolution signal of the interval from the base of the upper coccolith limestone to the calcareous mudstone above the upper oil shale. The calcite content is consistently between 70 and $80 \%$ in the upper coccolith limestone and therefore there is little effect of carbonate dilution on the palynomorph signal. The upper coccolith limestone shows a consistent and progressive increase in the abundance of structured palynomorphs that declines as the TOC rises into the upper oil shale. Within the upper oil shale the structured palynomorph content effectively declines to zero. However, as the upper oil shale terminates, the high abundance of structured palynomorphs returns before reducing to a persistently low background level in the calcareous mudstone and mudstone that overlie the White Stone Band. The pattern is somewhat different in the middle oil shale. Here the structured palynomorph content declines through the calcareous mudstone that underlies the lower coccolith limestone but then shows a marked increase within the middle oil shale. Resolution is then lost within the middle coccolith limestone, as this interval is not laminated. The three minor TOC peaks at the base of the upper coccolith limestones are coincident with similar peaks in atomic $\mathrm{H} / \mathrm{C}$ ratio and a low content of structured organic matter. They represent minor developments of oil shale.

The consistent association between the palynofacies groups meant that bisaccate pollen size (Fig. 1) was used as an independent measure of transport or distality. The size variation again shows the characteristic sawtooth profile with the carbonate laminae having consistently lower mean sizes and lower abundances. In general, the mean size is greater where the content of structured palynomorphs is greater. This is seen within the upper coccolith limestone to upper oil shale interval. Bisaccate pollen sizes also remain high within the upper oil shale despite the very marked reduction in structured palynomorphs.

\section{Interpretation}

These detailed petrographic and palynological observations highlight the dual biogenic input into the Kimmeridge Clay Formation. The carbonate production clearly originated from coccoliths. The presence of laminae dominated by coccoliths also clearly indicates their origin within blooms to the general exclusion of other plankton groups. Conversely, the high-TOC AOM-rich laminae cannot originate from coccoliths, as the organic carbon content in an individual coccolith is only a very small proportion of the carbonate content and can therefore never accumulate as an organic-matter-rich deposit. Hence, there has to be another source of organic matter. The only other microplankton group that both leaves a palaeontological record and is present in abundance is the dinoflagellate cysts. However, it is

Fig. 2. BSE images of representative White Stone Band fabrics. Scale bars represent $100 \mu \mathrm{m}$. Abbreviations: omes, organic matter elongate stringers; cpl, coccolith pellet; py, pyrite; omel, organic matter elongate lens; Q, quartz. Negative identification numbers are given in parentheses, e.g. (L23A5, 1-4). (a) Low-magnification photomosaic showing a coccolith limestone lithology, composed of layers of pure coccoliths, and layers that contain thin, discontinuous organic matter stringers (indicated by arrows). The calcite veins that cut this section (L25B2, 1-3) should be noted. (b) Photomosaic of a coccolith-rich organic lithology, divided by a less coccolith-rich organic layer. The organic matter is predominantly elongated stringers, and the carbonate is coccolithic. Apart from within the organic-carbon-rich central layer, the organic matter stringers are thin and discontinuous. Pelletal carbonate structures are less common than in (c), whereas coccolith stringers are abundant, resulting in a stringer, rather than a blebby fabric (L23A, 1, 2, 5, 6). (c) Coccolithrich lithology containing abundant organic matter stringers. This fabric occurs during transition from a coccolith limestone to an organic-rich shale. The organic matter stringers are laterally persistent, and the coccoliths are present in coalescing pelletal structures, resulting in a discontinuous blebby laminated fabric. The preferential situation of pyrite framboids with the organic matter stringers should be noted. Coccospheres are preserved within the coccolithic pelletal structures and there is a lack of other fabric components (L27A5, 1-4). (d) Graded bed in the lower oil shale revealing clastic influx. The planar base (arrows) and the abundance of sparry lenses and grains at the base of the bed should be noted. These lenses decrease in abundance and size, until the fabric is dominated by diffuse, amorphous and stringers of organic matter (L210A, 9, 10). (e) Sequence of organic-rich layers. A layer containing abundant quartz grains, some with pyritic overgrowth overlying an amorphous organic layer with abundant pyrite framboids and coccoliths. These are followed by two very organic carbon-rich layers dominated by amorphous organic matter, which are divided by a very thin coccolith-clay filament ( $1-5$ coccoliths thick and indicated by the arrows). The lack of pyrite framboids in these two organic-rich layers should be noted. Above, this level deposition returns to an organic-dominated fabric with abundant coccoliths and pyrite framboids (L27B, 9, 10). (f) Pelletal lens composed of sparite crystals. The irregular boundary of the lens as a result of the euhedral crystals should be noted. These sparite crystals formed by diagenetic replacement (see (g)) of a coccolith pellet (L210A, 4). (g) Pelletal coccolith lens dominated by coccospheres. These are visible as the hollow spheres within the pellet. Internally the coccolith plates are disorganized but well preserved. There is a lack of other fabric components in this and other similar pellets (L27B, 1). 

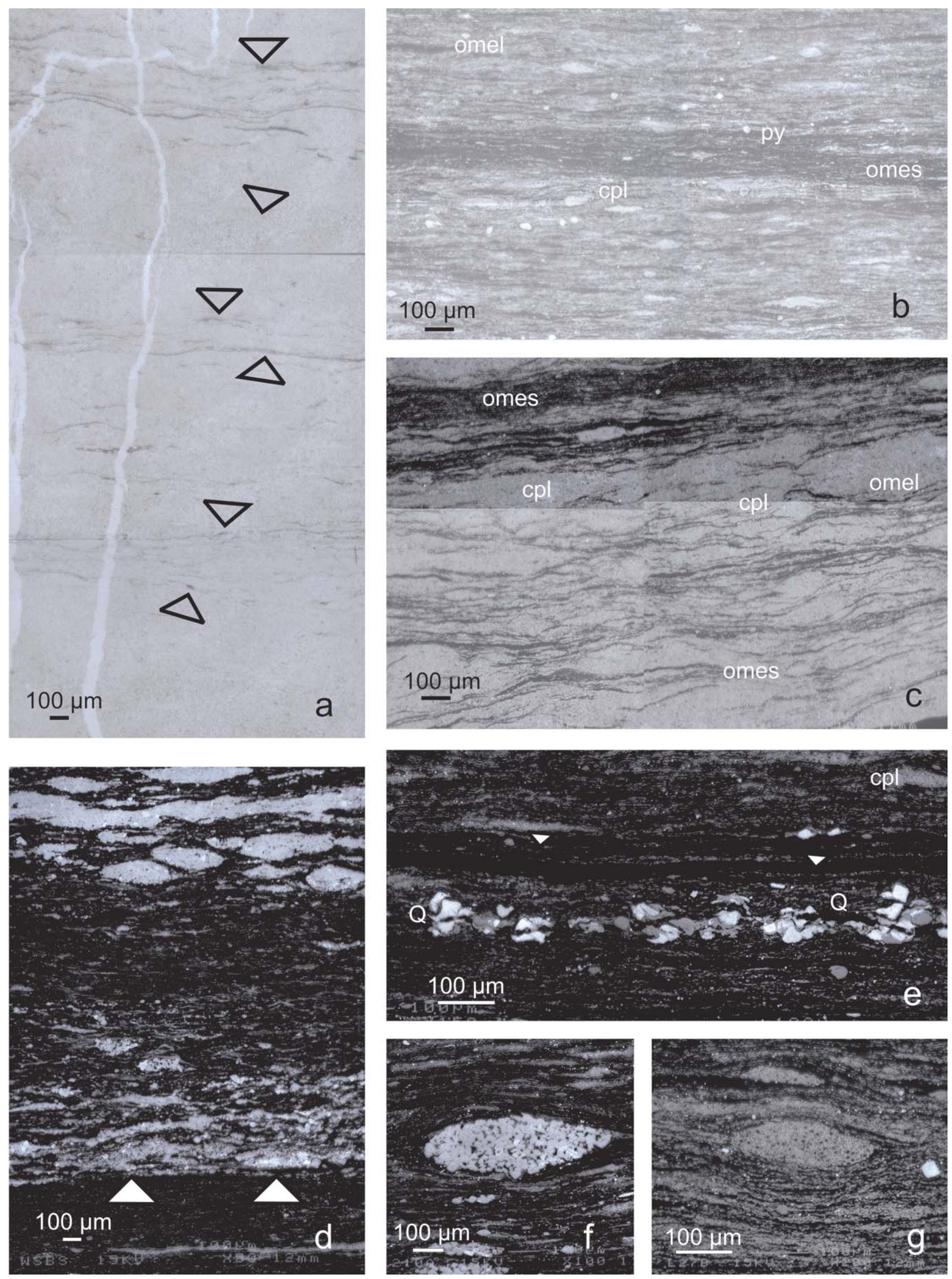


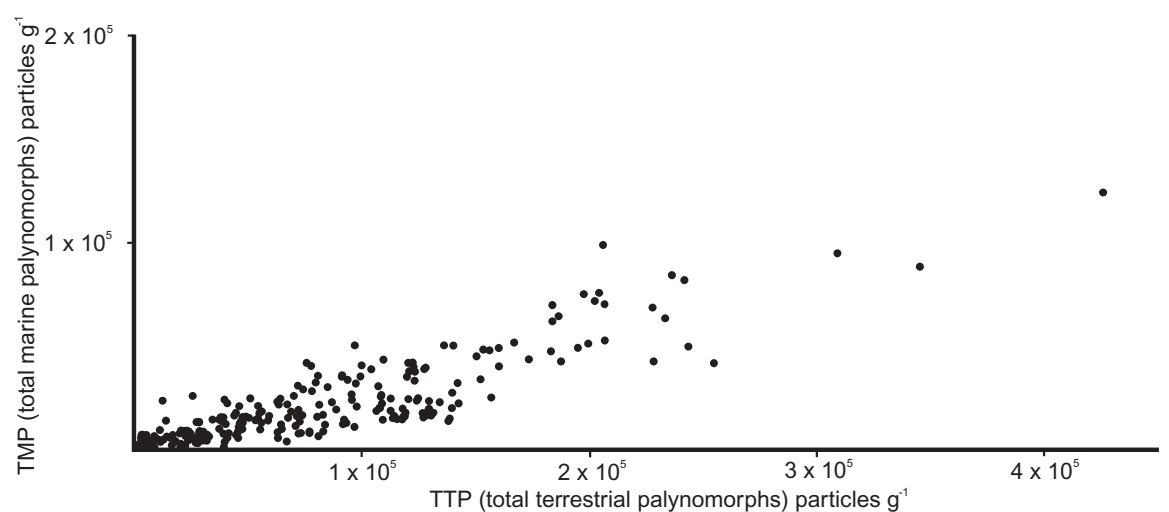

Fig. 3. Cross-plot of the abundance of terrestrial (TTP) and marine palynomorphs (TMP) in the White Stone Band. There is a very strong correlation $(r=0.85)$ between these abundances, showing that neither component was segregated through differential transport. well known (Fensome et al. 1993) that these cysts are not representative of the dinoflagellate standing crop, the great majority of the living cells never encysting to leave a potential fossil. However, the dinoflagellate cytoplasm can be preserved within the AOM. This was shown in the late Triassic Penarth Group (Thomas et al. 1993), where dinoflagellate-specific biomarkers (dinosterols) show abundances coincident with peaks in either dinocysts or AOM. Dinosterols, although less well tied to microfossil abundance, are also present within the AOM of the Kimmeridge Clay Formation, attesting to, in part, a dinoflagellate contribution to its origin (van Kaam-Peters et al. 1997). However, other biomarkers are present in the Kimmeridge Clay Formation that demonstrate an important contribution by groups that otherwise leave no fossil record. Significant here are the isorenieratene derivatives that occur particularly within the TOCrich intervals (van Kaam-Peters et al. 1998; Sælen et al. 2000; van Dongen et al. 2003). Isorenieratene is a biomarker specific to the Chlorobiaceae that are the brown strain of the photosynthetic green sulphur bacteria that require anaerobic conditions, a low light intensity and free $\mathrm{H}_{2} \mathrm{~S}$ in the water column. They are characterized by a very high $\delta^{13} \mathrm{C}$ value. Abundance peaks of this biomarker are strongly associated with the TOC peaks. This presence of abundant chlorobiacean bacteria demonstrates that during the time characterized by the TOC-rich intervals there was a stratified water column with euxinic conditions rising to within the photic zone.

The laminated character of parts of the White Stone Band interval with alternations of coccolith-rich and AOM-rich laminae therefore demonstrates the presence of successive blooms of coccoliths and dinoflagellates-chlorobiaceans accompanied by fluctuations in the depth of the euxinic water column as it rose into the photic zone during deposition of the organic-rich layers. A significant question is whether the coccolith-rich and organicmatter-rich pair represented an annual couplet as has been widely suggested (e.g. Oschmann 1988; Chambers et al. 2000). The BSEI study reported here has shown that the development of the lamination is not simple (Fig. 2). For example, within the oil shales the lamination varies from very thin organic-rich stringers and coccolithic stringers to far thicker carbonate lamina. Within the coccolith limestones the coccolith laminae are predominantly thicker than the thin organic-rich stringers, which can be thin and discontinuous rather than discrete laminae. This makes them difficult to distinguish. To be counted successfully these laminae need to be traced laterally within a BSE image, as the components are generally in the form of blebs, pellets and discontinuous stringers (Fig. 2b and c). Hence simply running an EDX transect line across the lamination trend will result in the appearance of alternating lamination. Despite these great variations in thickness and continuity it is conceivable that all these laminae couplets represent the same depositional time period of a year and that the thickness variability is due to the relative amounts of both carbonate and organic matter flux during different parts of that year. Laminae counts have been made for the different lithologies of the White Stone Band and gave the following compacted sedimentation rates per thousand years: thick coccolith lamina with thin organic stringers, $118 \mathrm{~cm}$; coccolith-rich oil shale, $17-29 \mathrm{~cm}$ (average $22.8 \mathrm{~cm}$ ); very organic-rich oil shale, $4.5-5 \mathrm{~cm}$. These value can now be compared with sedimentation rates determined using the Milankovitch calibrated time durations for the autissiodorensis and elegans ammonite zones (Weedon et al. 1999). These give values of 4.5 and $3 \mathrm{~cm} \mathrm{ka}^{-1}$, respectively. What these results show is that if the lamination couplets are annual then the coccolithdominated lithologies represent times of greatly enhanced deposition and would indeed give them the ability to resolve high-resolution seasonal events. The opposite situation prevailing at times of average sedimentation where a $4.5 \mathrm{~cm} \mathrm{ka}^{-1}$ accumulation rate would require preservation and resolution of laminae couplets totalling $45 \mu \mathrm{m}$ each year. Comparison with the formation of laminae in modern Black Sea sediments also suggests that caution should be used before applying lamination count data. Here sediment trap data show the absence of the 'yearly' coccolith bloom from one in every five annual cycles (Hay et al. 1990) and that conversely a large coccolith bloom can have the effect of diluting or preventing the development of the organicmatter-rich laminae (Lyons 1991).

Accepting that the lamination couplets represent processes that occurred on an annual scale, but not necessarily providing an annual record, allows further development of the analogy with the modern Black Sea (Murray, 1991). This, like the Kimmeridge Clay Formation sea, is an enclosed water mass with restricted circulation, a strong stratification and a euxinic water column. However, the analogy is restricted to the interaction of the upper oxic water column and photic zone with the lower euxinic water mass, as otherwise the two systems have very different basin geometries. The phytoplankton populations in the Black Sea show a sequence of blooms in different plankton groups during the year (Stelmakh et al. 1998). In the open waters of the Black Sea the winter cooling of the surface waters drives vertical convective mixing of the water column that gives an intense eutrophication and a nutrient flux comparable with that of oceanic upwellings. In coastal water the eutrophication is driven by terrestrial runoff. As light levels rise following the winter void, the diatoms are the first to bloom, probably because their 
rapid growth allows them to out-compete the other phytoplankton groups. Production declines following this initial diatom bloom. However, as light levels continue to increase, the photic zone extends downwards and the water column becomes more stable, allowing other phytoplankton groups to bloom, with the coccoliths in the upper part of the water column and dinoflagellates-chlorobiacean bacteria at somewhat lower levels. These summer blooms are controlled by the ability of these other groups to thrive at lower nutrient levels and also to use nutrients released by the 'regeneration' of dead diatoms. In the Jurassic seas of the Kimmeridge Clay Formation we can envisage (Fig. 4) a similar scenario. As coccoliths are the most abundant component within the Kimmeridge Clay Formation laminated sediments they were probably the first group to bloom each year, followed by the dinoflagellates. The strong stratification of the Kimmeridge Clay Formation water column would also ensure that there would be further productivity from the chlorobiaceans living at greater depth where the photic zone intersected with the water column euxinia.

The sawtooth character of the palynofacies abundance data from the laminated sediments, both above and below the upper oil shale, shows an association between peaks in the structured palynological input with the laminae that are relatively poor in carbonate, and hence coccoliths, but rich in AOM and have high TOC contents. Recalculating the data as carbonate-free abundances retains this sawtooth pattern (Fig. 1) and demonstrates that it is not the result of carbonate dilution. This association of the greatest anoxia with the highest terrestrial input is somewhat counter-intuitive, as the expectation would be that these would represent the most distal or deep environment. These peaks represent poorly sorted pulses of particles of both terrestrial and marine origin, which occur in a consistent ratio. It is also

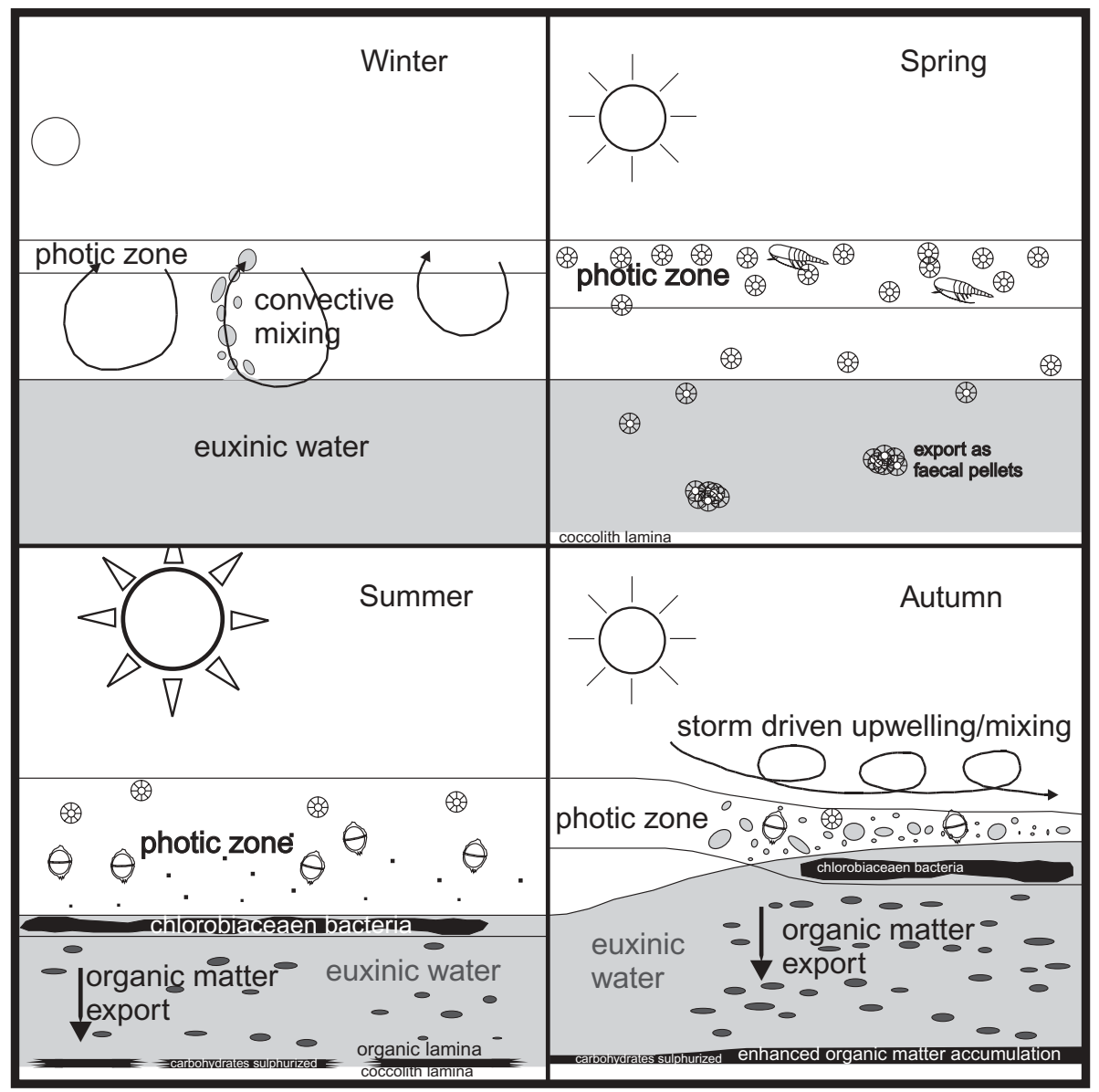

Fig. 4. Synthesis of possible events occurring during the annual cycle in the Kimmeridge water column and their sedimentological expression. Winter: during the winter phytoplankton void, the surface waters would have cooled with convective mixing that would have reached as deep as the euxinic water layer. This convective mixing recharged the shallower waters with nutrients. Spring: as light intensity increased there was an early plankton bloom of coccoliths followed by zooplankton grazers. Coccolith export to the bottom was largely through faecal pellets and resulted in the deposition of a prominent lamina. Summer: the main nutrient supply was exhausted by the coccolith bloom but as the photic zone extended downwards and nutrients were recycled, a more diverse plankton population became established. The coccoliths were present in the upper water column with dinoflagellates slightly deeper. As the photic zone intersected the euxinic water column the chlorobiacean bacteria bloomed. Any organic matter entering or being produced in the euxinic water column and settled through this water column now suffered minimal recycling through oxidation and this resulted in a significantly increased export of organic matter to the sea bed. This included carbohydrates that were then preserved by sulphurization. An organic-matter-rich lamina was variably developed. Autumn: in some autumn seasons, storms both depressed the sea surface and caused upwelling and mixing of the euxinic water column into the photic zone. This caused a late plankton bloom with all organic matter production that entered the euxinic water column undergoing minimal recycling by oxidation and accumulating as a thick organic matter lamina with preservation by sulphurization. The storms also brought in a wellmixed assemblage of terrestrial and marine palynological material. 
associated with an increase in the influx of larger-sized bisaccate pollen. However, apart from the size differentiation in the bisaccate pollen, there is clearly little evidence in the White Stone Band for differential transport and component degradation in the shelf environment but, instead, single and repeated influxes, of a well-mixed assemblage of both terrestrial and marine origin. Transport segregation and degradation was found only in Bed 44 (Pearson 2000). The most obvious transport mechanism for this material is by storm-driven resuspension events that would emplace well-mixed non-transport segregated material from nearshore areas into the more distal Kimmeridge Clay Formation environment. The difference in size between the bisaccate pollen in the carbonate and organic-matter-rich lamina represents the increased ability of these events to transport somewhat larger-sized particles. The way that the organic-matterrich laminae progressively build up into the upper oil shale and then decline above it shows that they and the associated storm events were implicated in the switch to the oil shale depositional mode. Again, the Black Sea can be used as an analogue for the Kimmeridge system. In the Black Sea there is a late plankton bloom of coccoliths that is driven by storms that break up the stratification and transport nutrients into the photic zone. Modelling (Staneva et al. 1998) shows that these storms, often as single events, are very important in the transfer of nutrients into the photic zone, with much of the annual variation being caused by the particular meteorological events in that year. Therefore, by analogy, storm events in the White Stone Band (Fig. 4) would have both depressed the sea surface and caused eddies lifting the euxinic water higher into the photic zone. This would have caused localized upwelling with mixing of the upper stratified surface water and eutrophication. This would increase productivity but the greatest effect would be to reduce recycling of organic matter on its descent through the water column followed by the preservation of the carbohydrates by sulphurization after reaching the sea bed (van Dongen et al. 2003). Therefore, this late season production would contribute significantly, both in amount and quality, to the flux of organic matter to the sea bed to give a very organic-rich lamina that in volume would far overwhelm the normally more conspicuous coccolith lamina. Taking the $\times 2$ increased productivity values determined for the Blackstone with the $\times 18$ increase in preservation, the effect of water column euxinia on the White Stone Band middle oil shale (TOC $50 \%$, calcite $20 \%$ ) can be modelled. Removing the $\times 18$ preservation and $\times 2$ productivity effects and reproportioning the sum reduces the organic matter content to $2 \%$ with a recalculated calcite content of $38 \%$. These are effectively the normal Kimmeridge Clay Formation background values measured in homogeneous mudstone. Therefore it can be seen that the oil shale does not represent an interval where coccolith deposition was suspended but rather an episode where water column euxinia greatly enhanced export and preservation of non-coccolith production. This simple change produces an oil shale by diluting the other components. This mechanism explains the reduction in structured debris recorded in the oil shale, as the AOM production also swamps all the other kerogen components. In the central oil shale these relict pulses of structured organic matter are still recorded.

Accepting this storm-driven mechanism to both lift and mix the water column euxinia thus provides a simple and subtle cause of lithological change within the White Stone Band and more generally in the Kimmeridge Clay Formation. For example, as noted above, there is a gradual increase of storm-driven input rising into the upper oil shales and thereafter gradually declining. This implies an increase of storm frequency or magnitude that produces an oil shale. Although this input, as revealed by the structured palynological debris, cannot be seen in the upper oil shale the progressive increase and then decline in TOC into the oil shale suggests that the process continues to a maximum coincident with that of the oil shale. All that was required to produce an oil shale would be a subtle climatic change within the Milankovitch Band that shifted the movement and/or intensity of the storm track. This could lead to the development of a semi-permanent storm-driven gyre. The coccolith limestones represented times where the euxinic water column remained generally below the photic zone with reduced organic matter export. However, the presence of the sea-bed anoxia would have still preserved the lamination. This mechanism does not require any significant change in basin geometry and water depth within the White Stone Band system, a constraint on any highresolution climatic change within such a short time interval.

This analogy can be extended more generally to the typical mudstone sediment of the Kimmeridge Clay. During deposition there would be a (?)seasonal alternation of plankton blooms but without permanent water column euxinia. This would permit survival of an intermittent bottom-dwelling fauna whose activities would result in the mixing of the biogenic input to destroy any lamination. This alternation of phytoplankton during a season is envisaged as being the normal condition. However, subtle Milankovitch-driven climate change as defined by the TOC highs would result in a permanent stratification and the development of water column euxinia. This would remove the benthos and preserve the lamination. Seasonal highs that pushed this euxinic layer into the photic zone would then lead to the greatly increased preservation and the TOC maxima. Again, this climate change could be the very subtle switch of a storm track or increase in storm strength rather than significant reorganization of sea level and geometry within the basin.

There have been a plethora of models advanced to explain both the environment of the Kimmeridge Clay and its cyclicity. However, many of these have appealed to general comparisons with potential modern analogues. The lamina-scale approach used here allows comparison with modern analogues at a seasonal scale. This permits a more confident identification of the water column processes involved in deposition of the Kimmeridge Clay Formation.

This project was funded by the NERC (GST/02/1346) with additional support from the RGGE consortium of oil companies (Arco British, Conoco Norway, Enterprise, Fina, Phillips, Saga Petroleum, Shell, Statoil and Texaco). R. Williams provided essential core handling, and S. Akbari, R. Jones, J. Ford and R. Pearce gave invaluable technical assistance. H. Morgans-Bell, J. Dean, J. Pike and the RGGE 'cyclists' all contributed important technical discussion and advice.

\section{References}

Chambers, M.H., Lawrence, D.S.L., Sellwood, B.W. \& Parker, A. 2000. Annual layering in the Upper Jurassic Kimmeridge clay formation, UK, quantified using an ultra-high resolution SEM-EDX investigation. Sedimentary Geology, 137, 9-23.

Fensome, R.A., Taylor, F.J.R., Norris, G., Sarjeant, W.A.S., Wharton, D.I. \& Williams, G.L. 1993. A Classification of Living and Fossil Dinoflagellates. Micropalaeontology Special Publications, 7.

GalloIs, R.W. 2000. The stratigraphy of the Kimmeridge Clay (Upper Jurassic) in the RGGE Project boreholes at Swanworth Quarry and Metherhills, south Dorset. Proceedings of the Geologists' Association, 111, 265-280.

Hay, B.J., Honjo, S., Kempe, S., Ittekkot, V.A., Degens, E.T., Konuk, T. \& IZDAR, E. 1990. Interannual variability in particle flux in south western Black Sea. Deep-Sea Research, 37, 911-928.

House, M.R. \& Gale, A.S. (EDS) 1995. Orbital Forcing Timescales and Cyclostratigraphy. Geological Society, London, Special Publications, 85

LyONS, T.W. 1991. Upper Holocene sediments of the Black Sea: summary of Leg 
4 box cores (1988 Black Sea Oceanographic Expedition). In: Murray, J.W. \& IzDAR, E. (eds) Black Sea Oceanography. Kluwer, Boston, MA, 4, $401-441$.

MilleR, R.G. 1990. A palaeoceanographic approach to the Kimmeridge Clay Formation. In: Huc, A.Y. (ed.) Deposition of Organic Facies. AAPG, Tulsa, $13-27$.

Morgans-Bell, H.S., Coe, A.L. \& Hesselbo, S.P. et AL. 2001. Integrated stratigraphy of the Kimmeridge Clay Formation (Upper Jurassic) based on exposures and boreholes in south Dorset, UK. Geological Magazine, 138, 511-539.

Mudie, P.J. 1982. Pollen distribution in Recent marine sediments, eastern Canada. Canadian Journal of Earth Sciences, 19, 729-747.

Murray, J.W. 1991. Black Sea oceanography, results from the 1988 Black Sea Expedition. Deep-Sea Research, 38(Supplementary Issue 2A), S655-S1266.

Oschmann, W. 1988. Kimmeridge Clay sedimentation-a new cyclic model. Palaeogeography, Palaeoclimatology, Palaeoecology, 65, 217-251.

OschmanN, W. 1990. Environmental cycles in the late Jurassic northwest European epeiric basin: interaction with atmospheric and hydrospheric circulations. Journal of Sedimentary Geology, 69, 313-332.

Pearson, S. J. 2000. High-resolution environmental change in the Late Jurassic Kimmeridge Clay Formation. $\mathrm{PhD}$ thesis, University of Southampton.

Sælen, G., Tyson, R.V., Talbot, M.R. \& Telnaes, N. 2000. Contrasting watermass conditions during deposition of the Whitby Mudstone (Lower Jurassic) and Kimmeridge Clay (Upper Jurassic) formations, U.K. Palaeogeography, Palaeoclimatology, Palaeoecology, 163, 163-196.

Sinninghe Damsté, J.S., KoK, M.D., Köster, J. \& Schouten, S. 1998. Sulfurized carbohydrates: an important sedimentary sink for organic carbon. Earth and Planetary Science Letters, 164, 7-13.

Staneva, J.V., Stanev, E.V. \& Oguz, T. 1998. The impact of atmospheric forcing and water column stratification on the yearly plankton cycle. In: Ivanov, L.I. \& Oguz, T. (eds) Ecosystem Modeling as a Management Tool for the Black Sea. Kluwer, Dordrecht, 2, 301-322.

Stelmakh, L.V., Yunev, O.A., Finenko, Z.Z., Vedernikov, V.I., Bologa, A.S. \& Churilova, T.Y. 1998. Peculiarities of seasonal variability of primary production in the Black Sea. In: Ivanov, L.I. \& Oguz, T. (eds) Ecosystem
Modeling as a Management Tool for the Black Sea. Kluwer, Dordrecht, 1, 93-104.

Thomas, J.B., Marshall, J.E.A., Mann, A.L., Summons, R.E. \& Maxwell, J.R. 1993. Dinosteranes (4,23,24-trimethylsteranes) and other biological markers in dinoflagellate-rich, marine sediments of Rhaetian age. Organic Geochemistry, 20, 91-104.

Tyson, R.V. 1995. Sedimentary Organic Matter. Chapman \& Hall, London.

van Dongen, B.E., Schouten, S. \& Sinninghe Damsté, J.S. 2003. Preservation of carbohydrates through sulfurization: the primary cause of the accumulation of organic matter in a Jurassic euxinic shelf sea. Geologica Ultraiectina, 224, $107-145$.

van Kaam-Peters, H.M.E., Schouten, S., De Leeuw, J.W. \& Sinninghe DAmstÉ, J.S. 1997. A molecular and carbon isotope biogeochemical study of biomarkers and kerogen pyrolysates of the Kimmeridge Clay Facies: palaeoenvironmental implications. Organic Geochemistry, 27, 399-422.

van KaAm-Peters, H.M.E., Schouten, S., Köster, J. \& Sinninghe Damsté, J.S. 1998. Controls on the molecular and carbon isotopic composition of organic matter deposited in a Kimmeridgian euxinic shelf sea: evidence for preservation of carbohydrates through sulfurisation. Geochimica et Cosmochimica Acta, 62, 3259-3283.

WATERHOUSE, H.K. 1995. High resolution palynofacies investigation of Kimmeridgian sedimentary cycles. In: House, M.R. \& Gale, A.S. (eds) Orbital Forcing Timescales and Cyclostratigraphy. Geological Society, London, Special Publications, 85, 75-114.

WeEdon, G.P. 2003. Time-series Analysis and Cyclostratigraphy: Examining Stratigraphic Records of Environmental Cycles. Cambridge University Press, Cambridge.

Weedon, G.P., Jenkyns, H.C., Coe, A.L. \& Hesselbo, S.P. 1999. Astronomical calibration of the Jurassic time-scale from cyclostratigraphy in British mudrock formations. Philosophical Transactions of the Royal Society of London, Series A, 357, 1787-1813.

Weedon, G.P., Coe, A.L. \& Gallois, R.W. 2004. Cyclostratigraphy, orbital tuning and inferred productivity for the type Kimmeridge Clay (Late Jurassic), Southern England. Journal of the Geological Society, London, 161, $659-670$.

Received 28 May 2003; revised typescript accepted 11 November 2003.

Scientific editing by Helen Morgans-Bell and Anthony Cohen 